UDC $543.06+577.15+543.553$

\title{
Development of amperometric biosensor for choline determination
}

\author{
D. Yu. Kucherenko ${ }^{1,2}$, D. V. Siediuko ${ }^{3}$, D. V. Knyzhnykova ${ }^{2}$, \\ O. O. Soldatkin ${ }^{1,2}$, A. P. Soldatkin ${ }^{1,2}$ \\ ${ }^{1}$ Institute of Molecular Biology and Genetics, NAS of Ukraine \\ 150, Akademika Zabolotnoho Str., Kyiv, Ukraine, 03680 \\ ${ }^{2}$ Institute of High Technologies, Taras Shevchenko National University of Kyiv \\ 2, korp.5, Pr. Akademika Hlushkova, Kyiv, Ukraine, 03022 \\ ${ }^{3}$ National Aviation University \\ 1, Komarova, Kyiv, Ukraine, 03058 \\ didukh.d@gmail.com
}

\begin{abstract}
Aim. Development of an amperometric biosensor for measuring choline concentration in water samples. Methods. A bioselective element of the biosensor was created using choline oxidase which was covalently immobilized by glutaraldehyde crosslinking with bovine serum albumin on the surface of an amperometric platinum disk electrode. Results. The conditions of the bioselective element formation (the enzyme and glutaraldehyde concentrations, time of procedure) were optimized. The biosensor developed was characterized by good response reproducibility over hours of continuous operation. The linear range of substrate determination ranged from $10 \mu \mathrm{M}$ to $1000 \mu \mathrm{M}$, a limit of choline detection $-1-3 \mu \mathrm{M}$, the biosensor sensitivity was $25-$ $30 \mathrm{nA} / \mathrm{mM}$. An effect of interfering substances was significantly reduced by the application of an additional semipermeable poly-m-phenylenediamine (PPD) membrane. Conclusions. The developed biosensor is wellsuited for choline determination in water samples.
\end{abstract}

Ke y w or d s: biosensor, amperometric transducer, immobilized enzyme, choline oxidase, choline.

\section{Introduction}

Choline (2-oxyethyltrimethyl ammonium hydroxide) belongs to the vitamin-like substances [1]. It is an important ingredient for the nervous system due to the synthesis of neurotransmitter acetylcholine. The m onitoring of choline in blood serum is helpful to identify neurodegenerative diseases: Alzheimer's disease, Parkinson's disease, myasthenia gravis and disruption of cholinergic neurotransmission [2].

The choline deficiency leads to delays in the development and growth of organism, an increase in blood cholesterol level, fatty infiltration of the liver, varicose veins, high blood pressure and excess body weight $[1,3,4]$.
In clinical analysis, the choline quantification in biological samples is of great importance. Spectrophotometry, gas chromatography [5], mass spectrometry and chromatography-mass spectrometry [6] are known as mostly used physical and chemical methods for the choline identification. However, they are also known to have significant drawbacks: complicated and expensive equipment, requirement for qualified personnel, and laboriousness.

The way to overcome these challenges is the usage of new bioanalytical devices - biosensors. Many enzyme-based sensors have been developed for the choline detection, such as the amperometric enzyme sensor, electrochemiluminescent biosensor, amperometric aqueous sol-gel biosensor and chemilumines-

(C) 2016 D. Yu. Kucherenko et al.; Published by the Institute of Molecular Biology and Genetics, NAS of Ukraine on behalf of Biopolymers and Cell. This is an Open Access article distributed under the terms of the Creative Commons Attribution License (http://creativecommons.org/licenses/by/4.0/), which permits unrestricted reuse, distribution, and reproduction in any medium, provided the original work is properly cited 
cent flow sensor [7]. The amperometric biosensors are considered the most promising and successful among the electrochemical biosensors.

Thus, this work was aimed at the development of an amperometric biosensor for the quantitative analysis of choline in aqueous solutions. Moreover, this biosensor could be a part of the biosensor array for the simultaneous detection of several substances in future investigation.

\section{Materials and methods}

\subsection{Materials}

In the work we used the enzyme choline oxidase (ChOx), activity 15 unites/mg, from Sigma-Aldrich (Japan). Bovine serum albumin (BSA, fraction V), glycerol, HEPES, $50 \%$ aqueous solution of glutaraldehyde (GA), choline chloride and $m$-phenylenediamine were obtained from Sigma-Aldrich Chemie (Germany). $\mathrm{KH}_{2} \mathrm{PO}_{4}$ and other compounds were of Ukrainian production and of analytical purity grade.

\subsection{Preparation of bioselective elements}

In the work, the polyphenylenediamine (PPD) membrane was prepared by the method described in [8]. The procedure was as follows. The bare working electrodes were immersed in $5 \mathrm{mM}$ m-phenylenediamine solution, afterwards 10-12 cyclic voltammograms were obtained. Next, the enzyme membrane was deposited onto the PPD membrane.

The bioselective elements of biosensors were obtained by immobilization of the enzyme and additives on the surface of amperometric transducer with the PPD membrane .

The gel stock solution for preparation of the bioselective membrane contained $8 \%$ (hereinafter $\mathrm{w} / \mathrm{w})$ of ChOx, $4 \%$ of BSA, $10 \%$ of glycerol in $100 \mathrm{mM}$ phosphate buffer, $\mathrm{pH}$ 6.5. Glycerol was added to stabilize the enzymes during immobilization to prevent early drop drying and to improve the membrane adhesion to the transducer surface. Before deposition onto the transducer surface, the enzyme gel was mixed with $1.6 \%$ aqueous solution of glutaraldehyde (crosslinking agent) in a 1:1 ratio.
Immediately thereafter, the mixture was deposited onto the working surfaces of transducers and kept for $10 \mathrm{~min}$ in air at room temperature. After immobilization, the biosensors were washed in the working buffer from unbound components of a bioselective membrane and excess glutaraldehyde.

\subsection{Measuring procedure}

Three-electrode scheme of amperometric analysis was used. Platinum disc electrodes of our own fabrication [9] served as amperometric transducers. The working electrodes, auxiliary platinum electrode and $\mathrm{Ag} / \mathrm{AgCl}$ reference electrode were connected to the potentiostat PalmSens (Palm Instruments BV, Netherlands). The 8-channel device $(\mathrm{CH}-8$ multiplexer from the same manufacturer) connected to the potentiostat allowed simultaneous registration of the signals from eight working electrodes, but actually only two or three working electrodes were attached.

The measurements were carried out at room temperature in an open measuring cell, $3.5 \mathrm{ml}$ in volume, with constant stirring at a constant potential of $+0.6 \mathrm{~V}$ vs $\mathrm{Ag} / \mathrm{AgCl}$ reference electrode. The working buffer was $25 \mathrm{mM}$ HEPES, pH 7.4. All experiments were performed in triplicate. The substrate concentrations in the working cell were set by adding aliquots of the substrate stock solution.

\section{Results and discussion}

\subsection{Principle of biosensor functioning}

The functioning of amperometric biosensor for the choline determination is based on the enzymatic reaction (1), which takes place in a bioselective membrane resulting in choline oxidation and formation of electrochemically active hydrogen peroxide. While applying a positive potential, the hydrogen peroxide decomposion occurs on the electrode (2), which causes the current changes directly recorded by the amperometric transducer.

Choline oxidase

Choline $+\mathrm{O}_{2} \longrightarrow$ Betaine aldehyde $+\mathrm{H}_{2} \mathrm{O}_{2}$ 


$$
\mathrm{H}_{2} \mathrm{O}_{2} \stackrel{+0,6 \mathrm{~B}}{\longrightarrow} 2 \mathrm{H}^{+}+\mathrm{O}_{2}+2 \mathrm{e}^{-}
$$

First, the biosensor was submerged in the $3.5 \mathrm{ml}$ measuring cell filled with $25 \mathrm{mM}$ HEPES buffer (pH 7.4) and kept there for several minutes to obtain a stable baseline. Then aliquots of the stock choline solution were added and the signals were obtained. The data were automatically processed and graphically displayed on the computer monitor.

\subsection{Choice of optimal conditions of choline oxidase immobilization}

The procedure of bioselective element immobilization is an important factor, which affects analytical characteristics and operation of the biosensor. The functioning of enzyme biosensors depends on the composition of bioselective element (the enzyme and GA concentrations and their ratio) and time of the immobilization.

As the first step, an optimal GA concentration was determined. The bioselective elements were prepared with the GA mass fraction in the membrane of $0.1 \%, 0.2 \%, 0.4 \%, 0.8 \%, 1 \%$ and $2.5 \%$. At low GA concentrations, the biosensor responses were low (Fig. 1), and they quickly decreased during repeated use. This was due to the weak binding of the

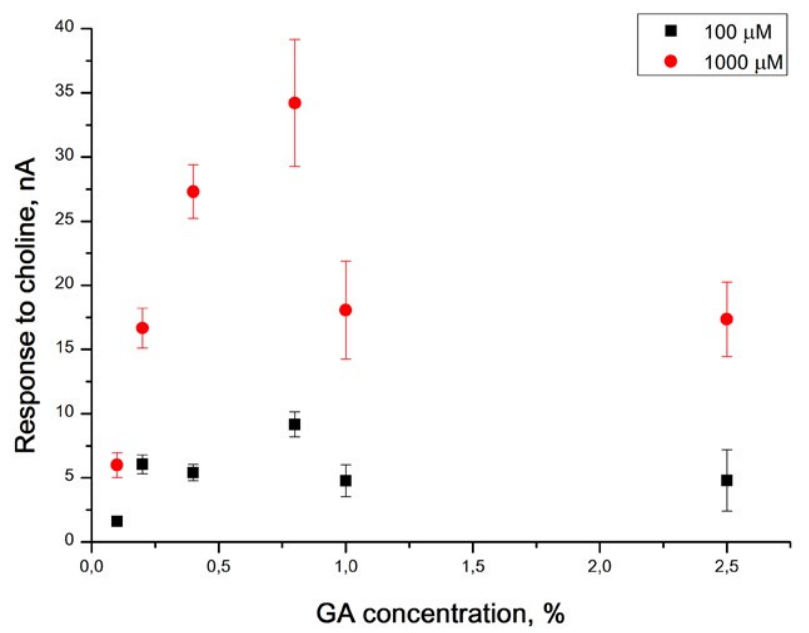

Fig. 1. Dependence of biosensor responses on GA concentration in bioselective membrane. Choline concentrations $-100 \mu \mathrm{M}$ and $1000 \mu \mathrm{M}$. Measurements were carried out in $25 \mathrm{mM}$ HEPES buffer, $\mathrm{pH} 7.4$, at constant potential of $+0.6 \mathrm{~V}$ vs Ag/ $\mathrm{AgCl}$ reference electrode. enzyme and its rapid leaching out the bioselective membrane. At high GA concentrations, the responses to choline were also low, this time because the cross-linking was too strong and the enzyme could not normally interact with the substrate.

In the further work, the membrane contains $0.8 \%$ of GA since at this concentration the biosensor responses to choline were the highest and most stable during the measurement.

Another important parameter, which influences the biosensor characteristics, is the enzyme concentration in biomembranes. To determine the optimal enzyme concentration, the bioselective elements with ChOx mass fractions of $1 \%, 2 \%, 4 \%$ and $6 \%$ were used. As seen (Fig. 2), the highest responses to choline were observed at concentrations of $4 \%$ and $6 \%$. Since these response values were about identical, in the further experiments the $\mathrm{ChOx}$ concentration in the bioselective element was $4 \%$.

The biosensors were also tested depending on the duration of bioselective element formation ranging from 5 to $40 \mathrm{~min}$. The highest responses to choline were observed when immobilization lasted $10 \mathrm{~min}$, at longer procedure the responses were significantly lower (Fig. 3).

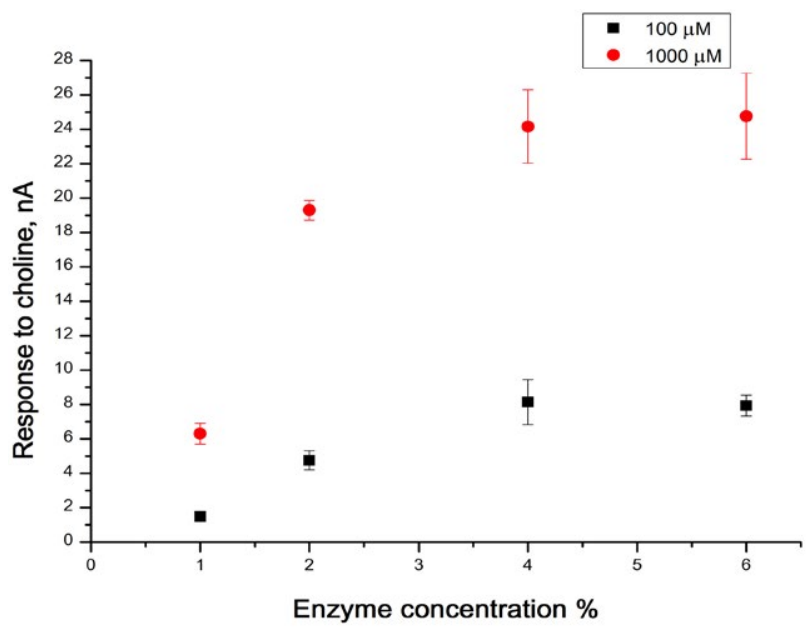

Fig. 2. Dependence of biosensor responses on ChOx concentration in bioselective membrane. Choline concentrations: $100 \mu \mathrm{M}$ and $1000 \mu \mathrm{M}$. GA concentration in membrane $-0.8 \%$. Measurements were carried out in $25 \mathrm{mM}$ HEPES buffer, $\mathrm{pH} 7.4$, at constant potential of $+0.6 \mathrm{~V}$ vs $\mathrm{Ag} / \mathrm{AgCl}$ reference electrode. 


\subsection{Reproducibility of biosensor responses}

Reproducibility of the biosensor response is one of the main characteristics of the efficiency of its operation. Therefore, the next step was to test the reproducibility of biosensor response during continuous operation. For the purpose, the responses to choline concentrations of $10 \mu \mathrm{M}, 100 \mu \mathrm{M}$ and $1000 \mu \mathrm{M}$ were measured over one working day (Fig. 4). One measurement lasted about 5 min, interval between measurements was about 10 min (during this time the biosensor was washed from the substrates changing the working buffer several times).

No notable decrease in the response value was observed during $4 \mathrm{~h}$ continuous operation ( 15 measurements); the relative standard deviation was $5-7 \%$.

\subsection{Selectivity of biosensor}

The mediatorless biosensor with relatively high operating potential ( $+0.6 \mathrm{~V} \mathrm{vs} \mathrm{Ag} / \mathrm{AgCl}$ reference electrode) was used, which made possible oxidation of a number of electroactive compounds (for example, ascorbic acid, uric acid and other) on the electrode surface. Therefore, the selectivity of amperometric electrode was improved by deposition of an additional polymer

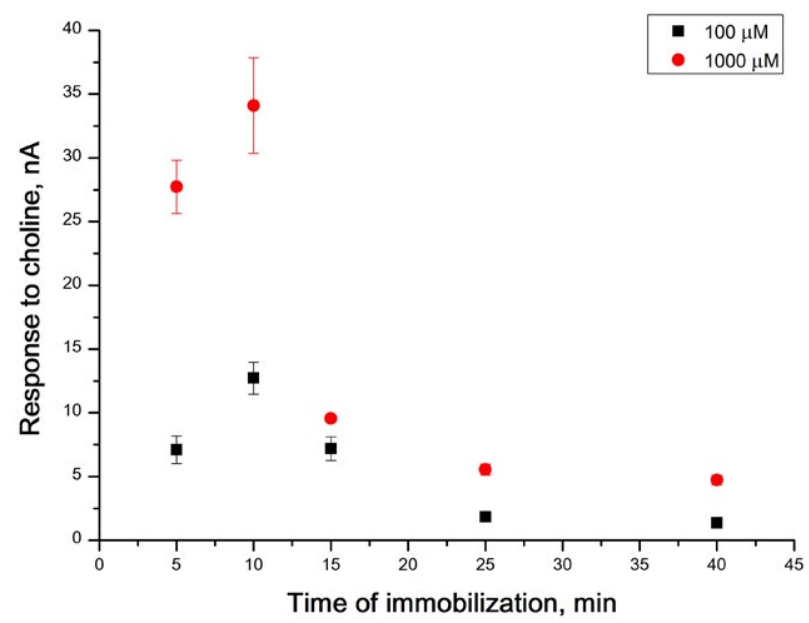

Fig. 3. Dependence of biosensor responses on time of immobilization. Choline concentrations: $100 \mu \mathrm{M}$ and $1000 \mu \mathrm{M}$. GA and ChOx concentrations in membrane $-0.8 \%$ and $4 \%$, respectively. Measurements were carried out in $25 \mathrm{mM}$ HEPES buffer, $\mathrm{pH} 7.4$, at constant potential of $+0.6 \mathrm{~V}$ vs $\mathrm{Ag} / \mathrm{AgCl}$ reference electrode. membrane, which limits the diffusion of interfering substances to the electrode surface. In the work, the poly- $m$-phenylenediamine (PPD) membrane was used.

To confirm the improvement of selectivity of the modified transducer, the electrodes sensitivity towards interfering substances was tested. The bare transducer reacted to certain substances quite strongly, which could be a problem while analyzing the real samples. The deposition of PPD membrane resulted in essential decrease or even complete absence of the biosensor responses to interferents whereas the sensitivity to hydrogen peroxide remained almost the same (Table 1). It was also found that the reproducibility of the biosensor signals to choline is significantly improved with the PPD membrane deposition due to better adhesion of biomembrane to the electrode.

\subsection{Analytical characteristics of biosensor for choline determination}

The linear working range of the biosensor and minimum limit of choline detection were determined.

The minimum limit of choline detection was defined as the choline concentration, the biosensor response to which was three times higher than the

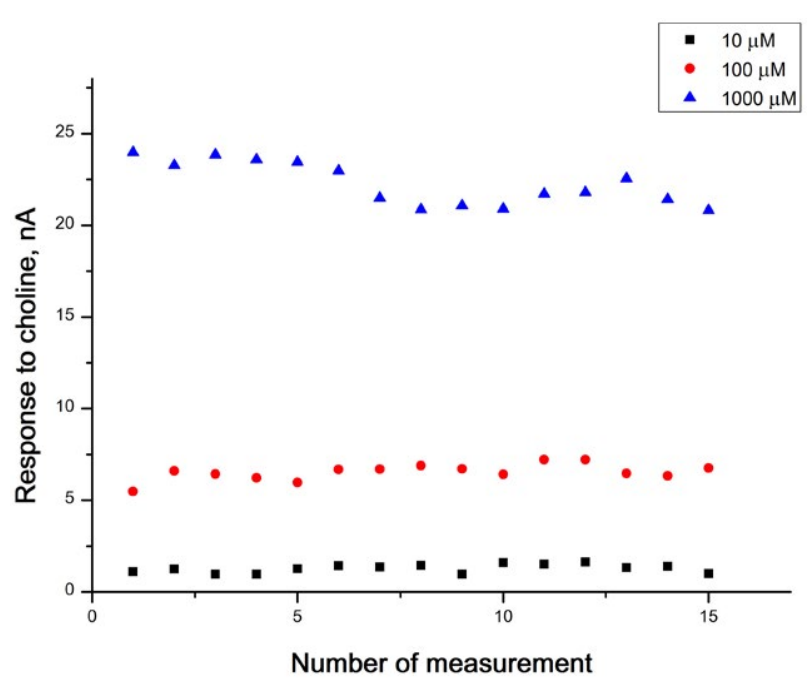

Fig. 4. Reproducibility of biosensor response. Choline concentrations - $10 \mu \mathrm{M}, 100 \mu \mathrm{M}$ and $1000 \mu \mathrm{M}$. Measurements were carried out in $25 \mathrm{mM}$ HEPES buffer, $\mathrm{pH} 7.4$, at constant potential of $+0.6 \mathrm{~V}$ vs Ag/ $\mathrm{AgCl}$ reference electrode. 
Table 1. Selectivity of amperometric transducer before and after deposition of PPD membrane

\begin{tabular}{|l|l|l|}
\hline \multirow{2}{*}{\multicolumn{1}{|c|}{ Possible interferent }} & \multicolumn{2}{c|}{ Respose, nA } \\
\cline { 2 - 3 } & $\begin{array}{c}\text { without PPD } \\
\text { membrane }\end{array}$ & $\begin{array}{c}\text { with PPD } \\
\text { membrane }\end{array}$ \\
\hline Hydrogen peroxide, $50 \mu \mathrm{M}$ & $34.7 \pm 2.6$ & $27.6 \pm 0.8$ \\
Ascorbic acid, $500 \mu \mathrm{M}$ & $33.2 \pm 1.7$ & $0.9 \pm 0.5$ \\
Dopamine, $20 \mu \mathrm{M}$ & $14.8 \pm 1.3$ & $1.2 \pm 0.3$ \\
Uric acid, $100 \mu \mathrm{M}$ & $10.6 \pm 1.8$ & 0 \\
Paracetamol, $100 \mu \mathrm{M}$ & $7.3 \pm 1.2$ & 0 \\
Cysteine, $100 \mu \mathrm{M}$ & $2.8 \pm 0.4$ & 0 \\
Citric acid, $500 \mu \mathrm{M}$ & 0 & 0 \\
Sodium chloride, $1 \mathrm{mM}$ & 0 & 0 \\
Potassium chloride, $1 \mathrm{mM}$ & 0 & 0 \\
Calcium chloride, $1 \mathrm{mM}$ & 0 & 0 \\
\hline
\end{tabular}

baseline noise; it was found to be $1-3 \mu \mathrm{M}$. This value slightly varied for different biosensors but increased as the biosensor was further used. The linear working range was from $10 \mu \mathrm{M}$ to $1000 \mu \mathrm{M}$, the biosensor sensitivity $25-30 \mathrm{nA} / \mathrm{mM}$. The typical calibration curve of the biosensor for choline determination is shown in Fig. 5.

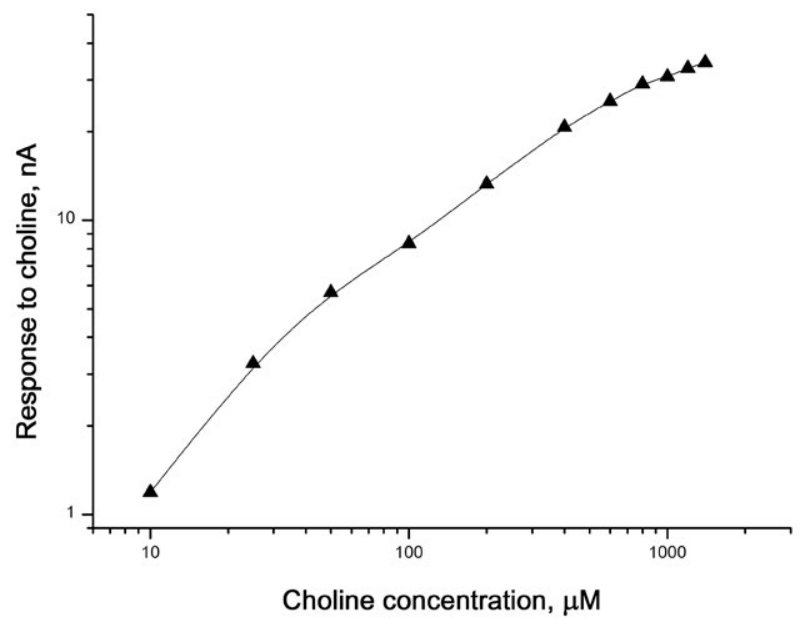

Fig. 5. Calibration curve of biosensor for choline determination. Measurements were carried out in $25 \mathrm{mM}$ HEPES buffer, $\mathrm{pH} 7.4$, at constant potential of $+0.6 \mathrm{~V}$ vs $\mathrm{Ag} / \mathrm{AgCl}$ reference electrode.

\section{Conclusions}

The biosensor based on choline oxidase has been developed for the choline determination in aqueous solutions. The optimum conditions of the enzyme immobilization by glutaraldehyde crosslinking with bovine serum albumin on the transducer surface were found to be as follows: GA concentration $0.8 \%$, ChOx concentration $-4 \%$, time of immobilization - 10 min. Reproducibility of the biosensor response to choline was investigated over one working day, the relative standard deviation was 5-7\%. It has been shown that the application of PPD membranes on the transducer surface before the bioselective element deposition resulted in a significant decrease in an impact of the main possible in biological fluids interferents on the biosensor operation.

The basic analytical characteristics of the developed biosensor were determined. They were as follows: linear range of choline determination - 10$1000 \mu \mathrm{M}$, minimum limit of detection $-1-3 \mu \mathrm{M}$, sensitivity - 25-30 nA/mM. This biosensor is planned to be further used for the measurement of choline concentration in real biological samples. It could be also a part of the biosensor array for simultaneous measurement of several substances.

\section{Funding}

The authors gratefully acknowledge the financial support of this study by the National Academy of Sciences of Ukraine in the frame of Scientific and Technical Government Program "Sensor systems for medicoecological and industrial-technological requirement: metrological support and experimental operation".

\section{REFERENCES}

1. Forbes GB, Woodruff $C W$. Pediatric nutrition handbook. American Academy of Pediatrics, Elk Grove Village, Ill, The Academy. 1985.

2. Wise D, Barkhimer T, Brault P, Kirchhoff J, Messer W, Hudson $R$. Internal standard method for the measurement of choline and acetylcholine by capillary electrophoresis with electrochemical detection. J Chromatogr B Analyt Technol Biomed Life Sci.. 2002;775(1):49-56.

3. Zeisel SH. "Vitamin-like" molecules. In: Eds. Shils ME, Young VR, Modern Nutrition and Health and Disease, 
Modern Nutrition in Health and Disease, 7th ed. Lea \& Febiger, Philadelphia. 1988; 440-52 p.

4. Zeisel SH, Da Costa KA, Franklin PD, Alexander EA, Lamont JT, Sheard NF, Beiser A. Choline, an essential nutrient for humans. FASEB J. 1991;5(7):2093-8.

5. Buchanan DN, Fucek FR, Domino EF. Paired-ion high-performance liquid chromatographic assay for plasma choline. J Chromatogr. 1980;181(3-4):329-35.

6. Lehmann WD, Schulten H-R, Schröder N. Determination of choline and acetylcholine in distinct rat brain regions by stable isotope dilution and field desorption mass spectrometry. Biol Mass Spectrom. 1978;5(10):591-5.

7. Li Y, Huang H, Shi F, Li Y, Su X. Optical choline sensor based on a water-soluble fluorescent conjugated polymer and an enzyme-coupled assay. Microchim Acta. 2013; 180(11-12):1135-40.

8. Killoran SJ, O'Neill RD. Characterization of permselective coatings electrosynthesized on Pt-Ir from the three phenylenediamine isomers for biosensor applications. Electrochim Acta. 2008;53(24):7303-12.

9. Soldatkin O, Nazarova A, Krisanova N, Borysov A, Kucherenko D, Kucherenko I, Pozdnyakova N, Soldatkin A, Borisova T. Monitoring of the velocity of high-affinity glutamate uptake by isolated brain nerve terminals using amperometric glutamate biosensor. Talanta. 2015;135:67-74.

\section{Розробка амперометричного біосенсора для визначення холіну}

Д. Ю. Кучеренко, Д. В. Сєдюко, Д. В. Книжникова, О. О. Солдаткін, О. П. Солдаткін

Мета. Розробка амперометричного біосенсора для визначення концентрацій холіну у водних зразках. Методи. Для створення біоселективного елементу біосенсора використовували холін оксидазу, що була іммобілізована ковалентною зшивкою глутаровим альдегідом з бичачим сироватковим альбуміном на поверхню амперометричного дискового платинового електроду. Результати. Було проведено оптимізацію умов формування біоселективного елементу на поверхню перетворювача (концентрація ферменту і глутарового альдегіду та час іммобілізаціі). Біосенсор характеризується доброю відтворюваністю відгуків впродовж декількох годин безперерв- ної роботи. Лінійний діапазон визначення субстрату знаходився в межах від 10 мкМ до 1000 мкМ, мінімальна межа визначення холіну - 1-3 мкМ, чутливість біосенсора 2530 нА/мМ. Завдяки використанню додаткової напівпроникної мембрани з полі-m-фенілендіаміну (ПФД) було значно зменшено вплив інтерферентів на роботу біосенсора. Висновки. Показано, що розроблений біосенсор добре підходить для визначення холіну у водних зразках.

Кл юч о в і с л о в а: біосенсор, амперометричний перетворювач, іммобілізований фермент, холін оксидаза, холін.

\section{Разработка амперометрического биосенсора для определения холина}

Д. Ю. Кучеренко, Д. В. Седюко, Д. В. Книжникова, А. А. Солдаткин, А. П. Солдаткин

Цель. Разработка амперометрического биосенсора для определения концентраций холина в водных образцах. Методы. Для создания биоселективного элемента использовали холин оксидазу, иммобилизованную ковалентной сшивкой глутаровым альдегидом с бычьим сывороточным альбумином на поверхность амперометрического дискового платинового электрода. Результаты. Была проведена оптимизация условий формирования биоселективного елемента на поверхность преобразователя (концентрация фермента и глутарового альдегида та время иммобилизации). Биосенсор характеризируется хорошей воспроизводимостью откликов на протяжении нескольких часов непрерывной работы. Линейный диапазон определения субстрата находился в пределах от 10 мкМ до 1000 мкМ, минимальная граница определения холина - 1-3 мкМ, чувствительность биосенсора 25-30 нА/мМ. Благодаря использованию дополнительной полупроницаемой мембраны с поли-м-фенилендиамина (ПФД) было значительно уменьшено влияние интерферентов на работу биосенсора. Выводы. Показано, что разработанный биосенсор хорошо применим для определения холина в водных образцах.

Кл ючевы е сл ов а: биосенсор, амперометрический преобразователь, иммобилизированный фермент, холин оксидаза, холин.

Received 25.04.2016 